\title{
CIRCUMCISION TRADITION (RECONSTRUCTION OF KNOWLEDGE FROM CIRCUMCISION PRACTICE IN NON- MUSLIM MEN IN MEDAN)
}

\author{
Dewantara Bangun and Lister Berutu \\ Universitas Sumatera Utara \\ listerberutu60@gmail.com
}

\begin{abstract}
Keywords: Circumcision, Knowledge Reconstruction, Culture.
Abstract: $\quad$ This research aims to discuss non-Muslim men's knowledge about circumcision practices that have done both pieces of knowledge about the meaning of circumcision and how to circumcision. Besides, to know various reasons, they practice circumcision. The method used is an ethnographic method with in-depth observation and interview techniques, by jumping directly into the research field at Sunatan House and Dr. Pirngadi Hospital Medan. The result of the study is that non-Muslim men interpret circumcision as cutting the tip of the penis, which can clean the impurities attached to the end of the penis and avoid various diseases. While the reason they commit circumcision is categorized into two categories, namely health and culture.
\end{abstract}

\section{INTRODUCTION}

Culture is a work created by the society that can be studied and passed on to the next generation through generations. Culture can also be used as a control tool for human behavior. Also, culture can be seen as values that are believed to be shared in society and can be internalized in individuals so that it is lived in every behavior. So it can be concluded that culture is the whole system of ideas, actions and works of man in the framework of people's lives that belong to man by learning (Koentjaraningrat, 2000: 180).

Culture and society are one unit that cannot be separated from each other. Culture is the result of human cultivation and power that elevates the degree of man as the highest being of God among other beings. With the culture, it can be known the level of civilization of a society. However, be aware that the level of culture and civilization is determined by human ability in the face of environmental challenges or the environment in which the human being lives and lives.

Cultural elements are language, social organization, knowledge system, living equipment, and technology system, livelihood system, religious system, and arts (Koentjaraningrat, 2000: 294). One example of the culture in society is the tradition of circumcision or circumcision. Circumcision is a tradition that has been around for a long time and lasts until now in society for various reasons such as religion and socio-cultural.

Circumcision is the cutting of part of the genital organs, the implementation of circumcision almost every place i.e., the cutting of the foreskin (Gulf) of the male penis. Circumcision, or often known in society as circumcision can be seen from two perspectives, cultural and religious. The tradition of circumcision today still takes place in various cultures. Circumcision is often seen as a sacred event, as is the case with marriage ceremonies. This is not separated from its origin, which turns out to indicate cultural value first.

The intended culture, as emphasized by Durkheim (1985), is something different beyond the individual's will, beyond the individual's ability, and imposes its will on each individual. Social pressures often dissuade individuals from doing the things they want. Culture is a societal pressure that includes patterns of thinking, feeling, and acting that are learned and transformed from one generation to the next. However, culture can change because of its adaptive nature.

Man in behavior is not only based on the will of his thoughts. That thought will experience the inclusion of external reality that is then processed in 
the human connective. If the thought is approved, then there will be an act of circumcision as an expression of acceptance of the values that exist around it. Human behavior consists of three factors: affective, congestive, and psychomotor, in individual psychomotor measured through the practice or behavior of the individual. Practice or behavior has four levels, namely, perception, first response, mechanism, and adaptation. Thus the practice done based on knowledge will produce something more than a practice based on knowledge.

Before an individual accepts a new behavior, there is a process that takes place in the sequence. This process includes awareness, will, evaluation, trial, and adoption (Simon-Marton, 1995). The behavior occurs due to the experience and results of an individual's interaction with his environment, especially when it comes to the individual's knowledge and attitude towards the object. So is the case in circumcision practice.

Fishbein and Ajzen (1975) state that an individual's participation in an activity is closely related to knowledge, attitude, intention, and behavior. There is no intention in carrying out the recommended practice depending on the positive or negative value. The practice is carried out not only because of attitudes but also because of beliefs, norms in society, and the intention to perform or practice it. When viewed from the history of circumcision, circumcision has been done regularly since 6,000 years ago in the southern part of Africa, starting from Libya, Egypt, the Middle East, South America, Australia, and Southeast Asia. At that time, circumcision was carried out for religious reasons, where human beings were punished for not committing deviant and excessive sexual acts. De Meo, states that any form of genital cutting, such as circumstance is a ritual belief that begins with a primitive religion that has nothing to do with medical, health or science reasons (Arival, 1996).

The tradition of circumcision in ancient Egyptian society is indicative of a painting on the walls of Saqqara found tombs by ankh-mahor from dynasty VI old kingdom (2350 BC). Compare this to the circumcision tradition first recorded in the Bible at Abraham's time (c. 1900 BC). Circumcision rituals were also well known among Arabs during the pre-Islamic Flavius Josephus, a Jewish historian from the first century AD. It referred to the circumcision ritual, also known to Arab tribes at the time. So it can be concluded that the circumcision tradition is neither the original tradition of the Hebrew nation nor Islam.
Circumcision is mandatory for men who are Muslim (Marshafi, 1996:13). However, some nonMuslim men commit circumcision even though it is not obligatory by their religion's teachings. NonMuslim males who commit circumcision have various reasons, one of which is the reproductive system.

Medan is one of the cities in Indonesia with a multicultural society with various tribes and religions. Based on the data of the Central Bureau of Statistics 2015, when seen from the most religious in the embraced, as a large population of North Sumatra province converted to Islam, the next is Christianity, Catholicism and Buddhism (BPS, 2015).

The situation and conditions described above make researchers interested in researching the community's knowledge from circumcision practices carried out by ed Non-Muslim men in Medan. According to the teachings of non-Muslim religion, the practice of circumcision is not required or not obligatory. However, at this time, many non-Muslim men are found to practice circumcision for various reasons. In this study, researchers wanted to see how the knowledge of non-Muslim communities that practice circumcision, as well as what are the reasons and benefits felt for those who practice circumcision.

\section{RESEARCH METHODS}

In this study, the method used is the ethnographic method. Ethnography is the work of describing a culture. As Malinowski pointed out (1992:25), the purpose of ethnographic is to understand the point of view of the natives, his relationship with life, to get his views on his world. Not only do you study society, more than that, ethnography means learning from society. The essence of ethnography is the effort to look at the meaning of the actions of the events that befall the person we want to understand. Some of these meanings are expressed directly in the language, and many are accepted and conveyed only indirectly through words and deeds (Spradley, 1997).

The research techniques used are literature studies, participatory observation techniques, and indepth interviews. Literature study activities are conducted to find literature or reading sources in completing the writing and adjustment of data from the interview results. The data obtained in this study obtained from literature is supporting data, namely thesis, books, articles, and journals. 
Research with ethnographic methods requires researchers to make a participatory observation, in which the researcher acts as an observer that is part of the group he studied. In addition to conducting participatory observations, ethnographic methods also conduct in-depth interviews, build rapport (good relationships created between researchers and subjects/informants), and write field notes (data obtained from observations and interviews with informants) while in the field.

In this study, the informants were non-Muslim men, both Christian, Buddhist and Hindu, who practice circumcision in Medan. The location to find informants and data is in hospitals and clinics in Medan. Informants who research interviews are paramedics / mantri and doctors.

\section{RESULTS AND DISCUSSIONS}

Circumcision is a thing that is always carried out by almost every human being, initially

only in Muslim communities, but then the world of health suggests that circumcision is very good for health, especially for men who serve to clean the male reproductive tools of all kinds of bacteria or viruses that result in the onset of disease.

Circumcision is a practice that has long existed and is practiced by almost all Indonesians even though they are of different ethnicities and religions. Non-Muslim men in Medan also assume circumcision they will be spared all kinds of diseases. If circumcision in boys according to the Muslim community is carried out based on health and a marker that the child will enter adulthood or akil baligh, in contrast to the non-Muslim community, assume circumcision is done on the basis of health and there is no concern with religious teachings. As one of John's informants said, "that circumcision is cutting off the tip of the penis that can clean the dirt that sticks to the end of the penis and can keep us from various diseases."

The practice of circumcision is still carried out today by non-Muslim communities. For some families, non-Muslim circumcision has become like a tradition for those who are done hereditary. Fedrik Barth says that in an ethnic group, there is an origin that determines a person's identity or group and as a broad social boundary, whereby perpetuation in a cultural aspect can lead to a person or group being classified into membership of an ethnic group.

Based on the information that researchers get in the field, circumcision in non-Muslim communities in Medan is mostly done by doctors. All they know is that doctors can perform circumcision, although some do circumcision with mantri. As Mr. Marcel's informant said that all of his family circumcised with doctors, there was indeed a mantry, but he was more trusting of the doctor because of his parents who were also circumcised in the hospital.

The circumcision method that is often used is the Klamp method or often called the ring method that many children do, because it is designed to produce a safer circumcision, faster, and more sophisticated, the tool can only be used once and modern technology and and the child can do as usual and can directly wear panties. While the circumcision method that is widely used by adults is a way by electrokautery method or commonly known as laser.. The circumcision process with this technique takes 15 to 25 minutes and requires stitches and verban, and it is recommended to rest for one day. On the second day, the patient can have normal activities as usual.

According to the informant, Mr. Robert, who committed circumcision at the age of 26 , that he committed circumcision at Pirngadi Hospital about two years ago and used laser methods, which he thought was good because the circumcision and healing process was quite fast.

In addition, non-Muslim settlers also know circumcision by traditional methods. But with this method, the pain is also more pain and healing in the traditional way that uses ingredients that are believed to heal scars after circumcision. Mr. Josep's informant at Mitra Sehat Clinic learned the traditional circumcised from his old man who was circumcised by using dried coconut is shell as his sharply sharp knife. The circumcision process of using a dry coconut shell does not use anesthesia, only that the child who will be circumcised is told to soak in cold water to reduce the pain when circumcised.

In a family, the practice of circumcision starts with a parent, can be from an ancestor, grandfather, father, and finally, to a child, or even to a grandchild, all of this depends on the way one responds to this issue. Usually, in a family tradition, it will continue to cling on and last until any time. As well as circumcision, circumcision used to be different from circumcision now, where today nonMuslim communities believe more in doctors or paramedics than mantri.

In one family interviewed, a child who had been circumcising before will continue to carry out circumcision on their child later, based on parental factors and customs attached to their family. As the Rio informant stated that if for a good reason should 
be eliminated, and indeed he did circumcision not based on religion, but for health in the future.

Generally, circumcision is known among Muslims. In Islam, circumcision (circumcision or circumcision) is a custom that is a continuation of the millah or teachings of the Prophet Ibrahim a.s. At that time, Ibrahim a.s. (80 years old) was circumcised with a tool called qadum. In fact, babies less than a year old can already be circumcised. However, in Indonesia, this practice is generally done in children aged 5 - 7 years. Indeed, circumcision can avoid the onset of various diseases. For example, phimosis, paraphimosis, candidiasis, and malignant and pre-malignant tumors in the male genital area proved the circumcised male penis was more hygienic.

Many non-Muslims realized that circumcision is indeed beneficial for health, especially the vital organs of men. According to Rio's informant, he had been circumcising since graduating from elementary school and was only told by his parents. However, at the age of 20 , she finds out the benefits of circumcision, which is to avoid sexually transmitted diseases. Therefore when he was married and had a son, he told his children to circumcise and teach the benefits of circumcision were.

Psychologically, circumcision should be done when the child is already brave so that psychic trauma is more minimal. Or, when you are a baby. It can also be done outside the above time provisions, among others, if often urinary tract infections due to the cause of long khitan skin with the narrow outer urinary tract. About the techniques to be used, nowadays there are many options. There is a conventional way of cutting the khitan skin with a scalpel, with the help of electro counters or often called lasers. As 32-year-old informant Tony said, circumcision is better as a child or elementary school, and better as a baby. He only finds out now through reading books, where the benefits he feels are many, one of which is that the penis is more awake than dirt and easier to clean it, unlike before.

It was also stated by informant Roy ( 28 years) that circumcision is for health, whereby circumcision, it is easy to clean the penis, and if not cleaned, it causes dirt to stick to the end of the penis and makes many diseases of vital organs. Later, according to Mr. Valen's informant at Pirngadi Hospital, he was circumcised on the advice of his doctored cousin, whose cousin had been treating patients with venereal diseases and was required to circumcise.

As for the Aldi informant (27 years), that circumcision is solely due to religion, but for health and he is aware that circumcision has many health benefits, and it just so happens that his wife is a nurse who also knows the benefits of circumcision.

There is also a reason non-Muslim men commit circumcision due to culture. Culture is a way of life that is developed and shared by a group of people and passed down from generation to generation. Culture is formed from many complex elements, including religious and political systems, customs, languages, tools, clothing, buildings, and artwork. According to the informant Pak Zebua (year), who was accompanying his son circumcision, circumcision is a cultural reason for the Nias tribe and has been going on for generations.

In Nias traditional society, circumcision is often used as "famago mbawa" (mouth covering) is a person who is not entitled to argue or speak informal meetings, because it has not been used as a custom that is circumcision.

This view is mainly grown in the northern and central regions of Nias but is not governed by customary law. According to him, it is possible if the circumcision of Nia's males has not been considered an adult.

Similarly, the speech of Nias researcher friend, Siwajarman Zalukhu, that he was circumcised at the age of 11 and based on Nias culture. In contrast to the opinion of Mr. Zebua, who said circumcision is often used as a cover-up or if a person has not been circumcised, then he cannot argue a formal meeting. According to him, if Nia's man is not circumcised, then the man will bear the shame and be ostracized from his environment. According to him, all Nia's men should be circumcised because of the existing culture and done when they were children around the age of 6-11 years old, approximately elementary to junior high school.

\section{REFERENCES}

Durkheim, Emile. 1985. Aturan-Aturan Metode Sosiologi. Rajawali. Jakarta.

Koentjaraningrat. 2000. Pengantar Ilmu Antropologi. PT Rineka Cipta. Jakarta.

Marshafi, Saad. 1996. Khitan. Gema Insani Press. Jakarta.

Spradley, James P. 1997. Metode Etnografi. PT. Tiara Wacana. Yogyakarta. 